\title{
Kinetics of neutrophil engraftment in allogeneic stem cell transplantation
}

\author{
Akihisa Kawajiri ${ }^{1}$, Shigeo Fuji ${ }^{1}{ }^{2}$, Yoshihiro Inamoto ${ }^{1}$, Saiko Kurosawa ${ }^{1}$, Takashi Tanaka ${ }^{1}$, Ayumu Ito ${ }^{1}$, Keiji Okinaka ${ }^{1}$, \\ Sung-Won Kim¹, Takahiro Fukuda ${ }^{1}$
}

${ }^{1}$ Department of Hematopoietic Stem Cell Transplantation, National Cancer Center Hospital, Tokyo, Japan, ${ }^{2}$ Department of Hematology, Osaka International Cancer Institute, Osaka, Japan

\section{Abstract}

Primary graft failure is a lethal complication that occurs after allogeneic stem cell transplantation (allo-SCT) and requires retransplantation. We retrospectively assessed 1,355 patients who underwent allo-SCT at our institute. Following allo-SCT, the cumulative incidence of subsequent neutrophil engraftment was calculated each day after day 5 among patients with white blood cell (WBC) count $<100$ cells/ $\mu \mathrm{L}$ on the respective day. The number of patients with WBC count $<100$ cells/ $\mu \mathrm{L}$ at days 14, 21, and 28 were 372, 55, and 21, respectively. In patients with WBC count $<100$ cells $/ \mu \mathrm{L}$ on day 14 , the cumulative incidence of engraftment was lower in recipients of peripheral blood stem cells (PBSCs) and cord blood (CB) compared with recipients of bone marrow (BM) (BM vs. PBSCs vs. $\mathrm{CB}, 93 \%$ vs. $79 \%$ vs. $77 \%, P<0.01)$. In patients with WBC count $<100$ cells $/ \mu \mathrm{L}$ after day 14 , the cumulative incidence of engraftment in recipients of PBSCs became progressively lower ( $25 \%$ at day 21 and $0 \%$ at day 28 ). In patients with WBC count $<100$ cells/ $\mu \mathrm{L}$ on day 28 , the cumulative incidence of engraftment was $100 \%$ in patients with donor chimerism $\geq 95 \%$, while it was only $13 \%$ in those with chimerism $<95 \%(P<0.01)$. These data provide important information that could be useful in deciding the appropriate time for performing tests in patients with donor chimerism and in those that require retransplantation.

Key words: primary graft failure, engraftment, allogeneic transplantation

Submitted October 20, 2018; Accepted January 23, 2019; Published online April 1, 2019; Issued online May 10, 2019

Correspondence: Shigeo Fuji, Department of Hematopoietic Stem Cell Transplantation, National Cancer Center Hospital, 5-1-1 Tsukiji, ChuoKu, Tokyo 104-0045, Japan. E-mail: fujishige1231@gmail.com

\section{Introduction}

Allogeneic stem cell transplantation (allo-SCT) is an effective therapy for hematologic disorders. Out of various causes of non-relapse mortalities, primary graft failure is a life-threatening complication following allo$\mathrm{SCT}^{1}$. Prolonged and severe neutropenia in patients with primary graft failure may result in lethal infections ${ }^{2}$. The prognosis of patients with primary graft failure was reported to be extremely poor if they did not receive a salvage $\mathrm{SCT}^{3,4}$. A significant proportion of patients who suffer from primary graft failure can be rescued by salvage SCT; the probability of overall survival (OS) was reported to be $30-60 \%$ at one year after salvage $\mathrm{SCT}^{5,6}$. Given the dismal outcome without salvage SCT, salvage SCT is considered a valuable treatment option in patients with primary graft failure.
Various factors were reported to be associated with primary graft failure, which included stem cell source (cord blood $[\mathrm{CB}]$ compared to bone marrow $[\mathrm{BM}]$ ) or peripheral blood stem cells [PBSCs]), disease status at transplant, degree of human leukocyte antigen (HLA) disparity, presence of donor-specific antibodies (DSA), history of blood transfusion, cell numbers of transplanted grafts, and intensity of conditioning regimen ${ }^{1,7-12}$. However, all these factors are related to pre-transplant characteristics. There is scarce evidence regarding post-transplant factors that can predict the subsequent risk of primary graft failure $^{13,14}$. In patients without autologous hematopoietic recovery, prompt diagnosis of primary graft failure and subsequent salvage SCT are crucial, because a longer period of neutropenia increases the risk of severe infection. Therefore, an efficient strategy to diagnose or identify patients at high risk of primary graft failure as soon 
as possible after allo-SCT should be established.

In most cases, primary graft failure is diagnosed based on the degree of donor chimerism. However, the circumstances in which chimerism analysis should be performed in allo-SCT patients at high risk for primary graft failure without neutrophil recovery are not well established.

In the present study, to clarify the risk factors of primary graft failure, we assessed patients who did not have white blood cell (WBC) recovery on consecutive days after allo-SCT and estimated the probability of subsequent engraftment and mortality without engraftment and re-transplantation.

\section{Patients and methods}

A total of 1,367 allo-SCTs were conducted at the National Cancer Center Hospital between December 1996 and September 2015. Except 12 patients who had missing data of WBC count from day 0 to day 28, 1,355 patients were included in further analyses. This study was approved by the Institutional review board of the National Cancer Center and was conducted in accordance with the guidelines given in the Declaration of Helsinki.

On each day after day 5 following SCT, patients with WBCs $<100$ cells $/ \mu \mathrm{L}$ (i.e., count below the detection limit at our Institute) were evaluated. The study endpoints included neutrophil engraftment, mortality without engraftment, and retransplantation. Engraftment is defined as an absolute neutrophil count $>500$ cells $/ \mu \mathrm{L}$ for 3 consecutive days after $\mathrm{SCT}^{6}$. A descriptive statistical analysis was performed to assess the patients' characteristics. The patient characteristics were compared using the Chi-squared test for categorical variables, and the Mann-Whitney U test or Kruskal-Wallis test for continuous variables. The cumulative incidences of engraftment, mortality without engraftment and retransplantation were evaluated using the Fine and Gray model. In the Fine and Gray model for engraftment, mortality without engraftment and re-transplantation were defined as competing risks. Factors that were associated with a two-sided $\mathrm{p}$ value of less than 0.10 in the univariate analysis were included in a multivariate analysis. The final model was determined by backward stepwise selection. A two-sided $\mathrm{p}$ value of less than 0.05 was considered statistically significant.

The variables included in these analyses were as follows: sex (female vs male), sex mismatch (female to male vs. other), patient's age at the time of allo-SCT (age $\geq 40$ years vs. age $<40$ ), Eastern Cooperative Oncology Group performance status $(0-1 \text { vs. } 2-4)^{15}$, intensity of the conditioning regimen (myeloablative vs. reduced-intensity), use of total body irradiation (TBI) (yes vs. no), stem cell source (PBSCs vs. BM vs. CB), relation between donor and patient (related vs. unrelated), HLA disparity in the graft-versus-host and host-versus-graft direction assessed by allelic or serological typing of HLA-A, -B, -C and-DRB1 (8/8 matched vs. others), presence of HLA antibody or donor specific antibody (DSA) (yes vs. no, regardless of titer), use of anti-thymocyte globulin (ATG) (yes vs. no), immunosuppression (calcineurin inhibitor + MTX [methotrexate] vs. calcineurin inhibitor + MMF [mycophenolate mofetil]), disease risk (low risk vs. intermediate risk vs. high risk vs. very high risk defined by Disease Risk Index $)^{16}$, histories of documented infection until day of analyses after alloSCT (yes vs. no), histories of documented infection or febrile neutropenia until day of analyses after allo-SCT (yes vs. no), donor chimerism around day 28 ( $<95 \%$ vs. $\geq 95 \%$ ). All statistical analyses were performed with EZR ver 1.30 (Saitama Medical Center, Jichi Medical University, Tochigi, Japan) ${ }^{17}$, which is a graphical user interface for $\mathrm{R}$ (The R Foundation for Statistical Computing, version 3.2.2).

\section{Results}

Patient characteristics are shown in Table 1. In Table 2 , we demonstrate the characteristics of patients with WBCs $<100$ cells $/ \mu \mathrm{L}$ at day 14,21 , and 28 as representative patient characteristics. Status of infectious diseases represented the histories of infections prior to the days of analyses after allo-SCT. As a result, the proportions of patients who experienced infections increased at later time points.

Figure 1 shows the cumulative incidences of neutrophil engraftment in all patients and patients with WBCs $<100$ cells $/ \mu \mathrm{L}$ at day 14,21 , and 28 . Engraftment was achieved significantly early in patients that received PBSCs, followed by BM and CB, in the mentioned order (the cumulative incidence of engraftment at day 50: PBSCs vs. $\mathrm{BM}$ vs. $\mathrm{CB}=97 \%$ vs. $95 \%$ vs $75 \%, P<0.01$, Figure 1A). The cumulative incidences of death without engraftment and re-transplantation were significantly higher in recipients of $\mathrm{CB}$ than those in recipients of $\mathrm{BM}$ and PBSCs (Supplementary Figure 1, the cumulative incidence of death without engraftment at day 50: PBSCs vs. $\mathrm{BM}$ vs. $\mathrm{CB}=2.3 \%$ vs. $3.4 \%$ vs. $9.5 \%, P<0.01$, Supplementary Figure 1A; re-transplantation: PBSCs vs. $\mathrm{BM}$ vs. $\mathrm{CB}=0.4 \%$ vs. $0.6 \%$ vs. $6.7 \%, P<0.01$, Supplementary Figure 1B). In patients with $\mathrm{WBCs}<100$ cells $/ \mu \mathrm{L}$ at day 14 , the cumulative incidence of engraftment was highest in recipient of BM; however, the incidence in recipients of PBSCs was lower than BM (the cumulative incidence of engraftment at day 50: PBSCs vs. $\mathrm{BM}$ vs. $\mathrm{CB}=79 \%$ vs. $93 \%$ vs. $77 \%, P<0.01$, Figure 1B). At later time points, the cumulative incidence of engraftment became lower and was more apparent in recipient of PBSCs (the cumulative incidence of engraft- 
Table 1. Characteristics of patients

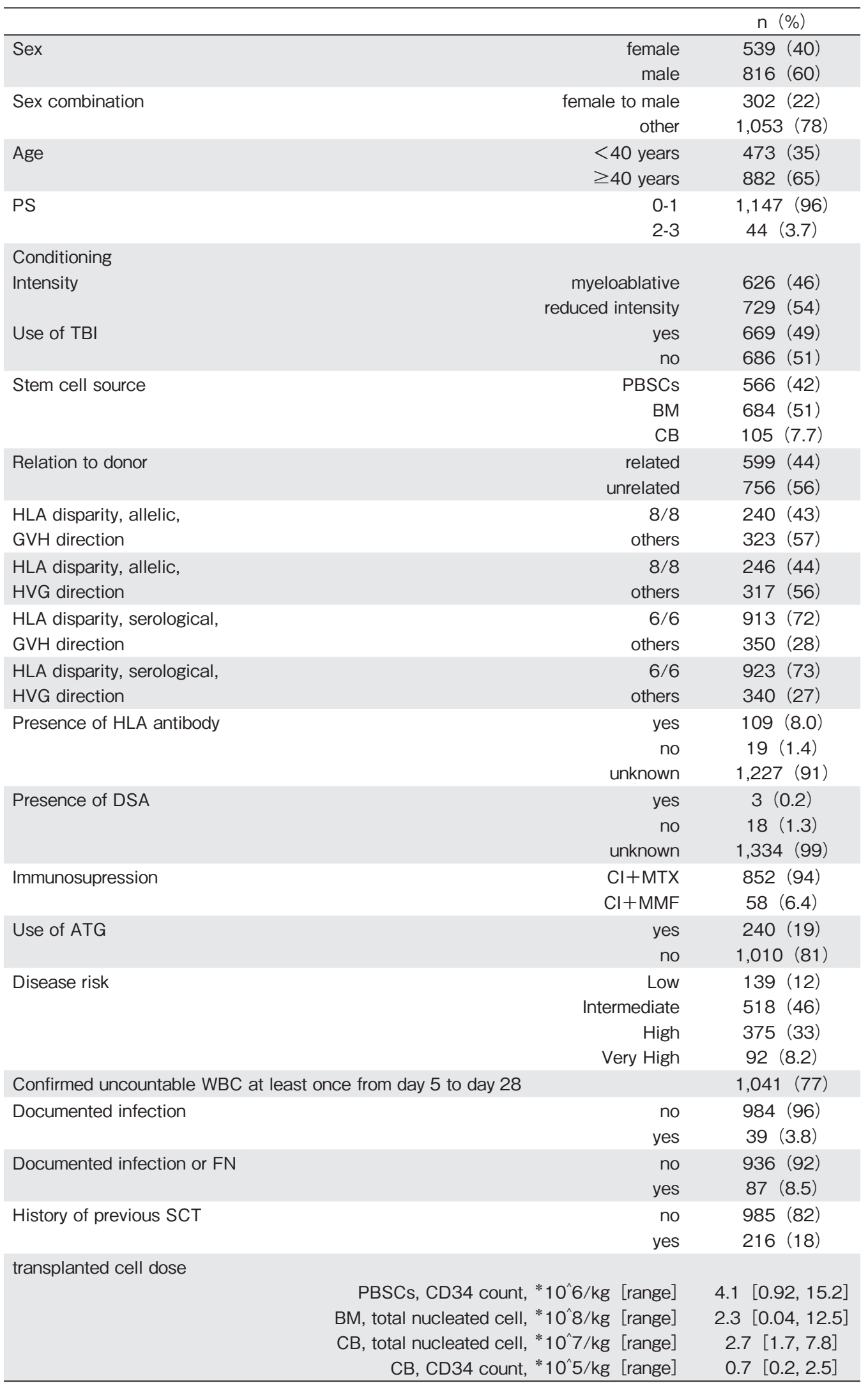

PS, performance status; TBI, total body irradiation; PBSCs, peripheral blood stem cells; BM, bone marrow; CB, cord blood; HLA, human leukocyte antigen; GVH, graft-versus-host; HVG, host-versus-graft; DSA, donor-specific antibodies; Cl, Calcineurin inhibitor; MTX, methotrexate; MMF, mycophenolate mofetil; ATG, anti-thymocyte globulin; WBC, white blood cell; FN, febrile neutropenia; SCT, stem cell transplantatuon. Characteristics of all patients who were included in the analyses $(n=1,355)$. 
Table 2. Characteristics of patients with WBCs $<100$ cells $/ \mu \mathrm{L}$ at day 14,21 , and 28

\begin{tabular}{|c|c|c|c|c|}
\hline \multicolumn{2}{|l|}{ n (\%) } & $\begin{array}{c}\text { day } 14 \\
372\end{array}$ & $\begin{array}{c}\text { day } 21 \\
55\end{array}$ & $\begin{array}{c}\text { day } 28 \\
21\end{array}$ \\
\hline Sex & $\begin{array}{r}\text { female } \\
\text { male }\end{array}$ & $\begin{array}{l}132(36) \\
240(65)\end{array}$ & $\begin{array}{ll}21 & (38) \\
34 & (62)\end{array}$ & $\begin{array}{c}9(43) \\
12(57)\end{array}$ \\
\hline Sex combination & $\begin{array}{r}\text { female to male } \\
\text { other }\end{array}$ & $\begin{array}{l}82(22) \\
290(78)\end{array}$ & $\begin{array}{l}13(24) \\
42(76)\end{array}$ & $\begin{array}{c}5(24) \\
16(76)\end{array}$ \\
\hline Age & $\begin{array}{l}<40 \text { years } \\
\geq 40 \text { years }\end{array}$ & $\begin{array}{l}125(34) \\
247(66)\end{array}$ & $\begin{array}{l}15(27) \\
40(73)\end{array}$ & $\begin{array}{c}5(24) \\
16(76)\end{array}$ \\
\hline PS & $\begin{array}{l}0-1 \\
2-4\end{array}$ & $\begin{array}{l}332(97) \\
12(3.5)\end{array}$ & $\begin{array}{cc}51 & (98) \\
1 & (1.9)\end{array}$ & $\begin{aligned} 21 & (100) \\
0 & (0.0)\end{aligned}$ \\
\hline Conditioning & & & & \\
\hline Intensity & $\begin{array}{l}\text { myeloablative } \\
\text { reduced intensity }\end{array}$ & $\begin{array}{l}209(56) \\
163(44)\end{array}$ & $\begin{array}{ll}21 & (38) \\
34 & (62)\end{array}$ & $\begin{array}{c}7(33) \\
14(67)\end{array}$ \\
\hline Use of TBI & $\begin{array}{r}\text { yes } \\
\text { no }\end{array}$ & $\begin{array}{l}246(66) \\
126(34)\end{array}$ & $\begin{array}{ll}35 & (64) \\
20 & (36)\end{array}$ & $\begin{array}{l}14(67) \\
7(33)\end{array}$ \\
\hline Stem cell source & $\begin{array}{r}\text { PBSCs } \\
\text { BM } \\
\text { CB }\end{array}$ & $\begin{array}{c}24(6.5) \\
305(82) \\
43(12)\end{array}$ & $\begin{array}{c}4(7.3) \\
43(78) \\
8(15)\end{array}$ & $\begin{array}{c}2(9.5) \\
13(62) \\
6(29)\end{array}$ \\
\hline Relation to donor & $\begin{array}{r}\text { related } \\
\text { unrelated }\end{array}$ & $\begin{array}{l}30(8.1) \\
342(92)\end{array}$ & $\begin{aligned} 5 & (9) \\
50 & (91)\end{aligned}$ & $\begin{array}{l}2(9.5) \\
19(91)\end{array}$ \\
\hline $\begin{array}{l}\text { HLA disparity, allelic, } \\
\text { GVH direction }\end{array}$ & $\begin{array}{r}8 / 8 \\
\text { others }\end{array}$ & $\begin{array}{l}127(46) \\
149(54)\end{array}$ & $\begin{array}{l}17(47) \\
19(53)\end{array}$ & $\begin{array}{ll}8 & (57) \\
6 & (43)\end{array}$ \\
\hline $\begin{array}{l}\text { HLA disparity, allelic, } \\
\text { HVG direction }\end{array}$ & $\begin{array}{r}8 / 8 \\
\text { others }\end{array}$ & $\begin{array}{l}128(46) \\
148(54)\end{array}$ & $\begin{array}{ll}16(44) \\
20(56)\end{array}$ & $\begin{array}{ll}7 & (50) \\
7 & (50)\end{array}$ \\
\hline $\begin{array}{l}\text { HLA disparity, serological, } \\
\text { GVH direction }\end{array}$ & $\begin{array}{r}6 / 6 \\
\text { others }\end{array}$ & $\begin{array}{l}260(71) \\
109(30)\end{array}$ & $\begin{array}{ll}35 & (64) \\
20 & (36)\end{array}$ & $\begin{array}{ll}11 & (52) \\
10 & (48)\end{array}$ \\
\hline $\begin{array}{l}\text { HLA disparity, serological, } \\
\text { HVG direction }\end{array}$ & $\begin{array}{r}6 / 6 \\
\text { others }\end{array}$ & $\begin{array}{l}260(71) \\
109(30)\end{array}$ & $\begin{array}{ll}36 & (66) \\
19 & (35)\end{array}$ & $\begin{array}{ll}10 & (48) \\
11 & (52)\end{array}$ \\
\hline Presence of HLA antibody & $\begin{array}{r}\text { yes } \\
\text { no } \\
\text { unknown }\end{array}$ & $\begin{array}{c}7(1.9) \\
43(12) \\
322(87)\end{array}$ & $\begin{array}{cc}0 & (0.0) \\
8 & (15) \\
47 & (86)\end{array}$ & $\begin{array}{ll}0 & (0.0) \\
2 & (9.5) \\
19 & (91)\end{array}$ \\
\hline Presence of DSA & $\begin{array}{r}\text { yes } \\
\text { no }\end{array}$ & $\begin{array}{cc}0 & (0.0) \\
8 & (2.2) \\
364 & (98)\end{array}$ & $\begin{array}{cl}0 & (0.0) \\
0 & (0.0) \\
55 & (100)\end{array}$ & $\begin{array}{cc}0 & (0.0) \\
0 & (0.0) \\
21 & (100)\end{array}$ \\
\hline Immunosupression & $\begin{array}{l}\mathrm{Cl}+\mathrm{MTX} \\
\mathrm{Cl}+\mathrm{MMF}\end{array}$ & $\begin{array}{c}333(97) \\
9(2.6)\end{array}$ & $\begin{array}{c}46(100) \\
0(0.0)\end{array}$ & $\begin{array}{cc}17 & (100) \\
0 & (0.0)\end{array}$ \\
\hline Use of ATG & $\begin{array}{r}\text { yes } \\
\text { no }\end{array}$ & $\begin{array}{c}53(14) \\
318(86)\end{array}$ & $\begin{array}{c}6(11) \\
49(89)\end{array}$ & $\begin{array}{c}1(4.8) \\
20(95)\end{array}$ \\
\hline Disease risk & $\begin{array}{r}\text { Low } \\
\text { Intermediate } \\
\text { High } \\
\text { Very High }\end{array}$ & $\begin{array}{cc}32 & (9.6) \\
153 & (46) \\
121 & (36) \\
27 & (8.1)\end{array}$ & $\begin{aligned} 3 & (6.1) \\
19 & (38.8) \\
22 & (44.9) \\
5 & (10)\end{aligned}$ & $\begin{array}{cc}1 & (5.6) \\
10 & (55.6) \\
6 & (33.3) \\
1 & (5.6)\end{array}$ \\
\hline Documented infection & $\begin{array}{r}\text { no } \\
\text { yes }\end{array}$ & $\begin{array}{c}250(73) \\
92(27)\end{array}$ & $\begin{array}{ll}22 & (44) \\
28 & (56)\end{array}$ & $\begin{array}{cc}6 & (28.6) \\
15 & (71.4)\end{array}$ \\
\hline Documented infection or FN & $\begin{array}{r}\text { no } \\
\text { yes }\end{array}$ & $\begin{array}{l}119(35) \\
223(65)\end{array}$ & $\begin{array}{ll}11 & (22) \\
39 & (78)\end{array}$ & $\begin{array}{c}1(4.8) \\
20(95)\end{array}$ \\
\hline History of previous SCT & $\begin{array}{r}\text { no } \\
\text { yes }\end{array}$ & $\begin{array}{c}305(82) \\
67(18)\end{array}$ & $\begin{array}{l}39(71) \\
16(29)\end{array}$ & $\begin{array}{c}15(71) \\
6(29)\end{array}$ \\
\hline Donor chimerism around day 28 & $\begin{array}{l}<90 \% \\
\geq 90 \%\end{array}$ & & & $\begin{array}{l}14(70) \\
6(30)\end{array}$ \\
\hline
\end{tabular}

WBC, white blood cell; PS, performance status; TBI, total body irradiation; PBSCs, peripheral blood stem cells; BM, bone marrow; $\mathrm{CB}$, cord blood; HLA, human leukocyte antigen; GVH, graftversus-host; HVG, host-versus-graft; DSA, donor-specific antibodies; Cl, Calcineurin inhibitor; MTX, methotrexate; MMF, mycophenolate mofetil; ATG, anti-thymocyte globulin; WBC, white blood cell; FN, febrile neutropenia; SCT, stem cell transplantatuon. 

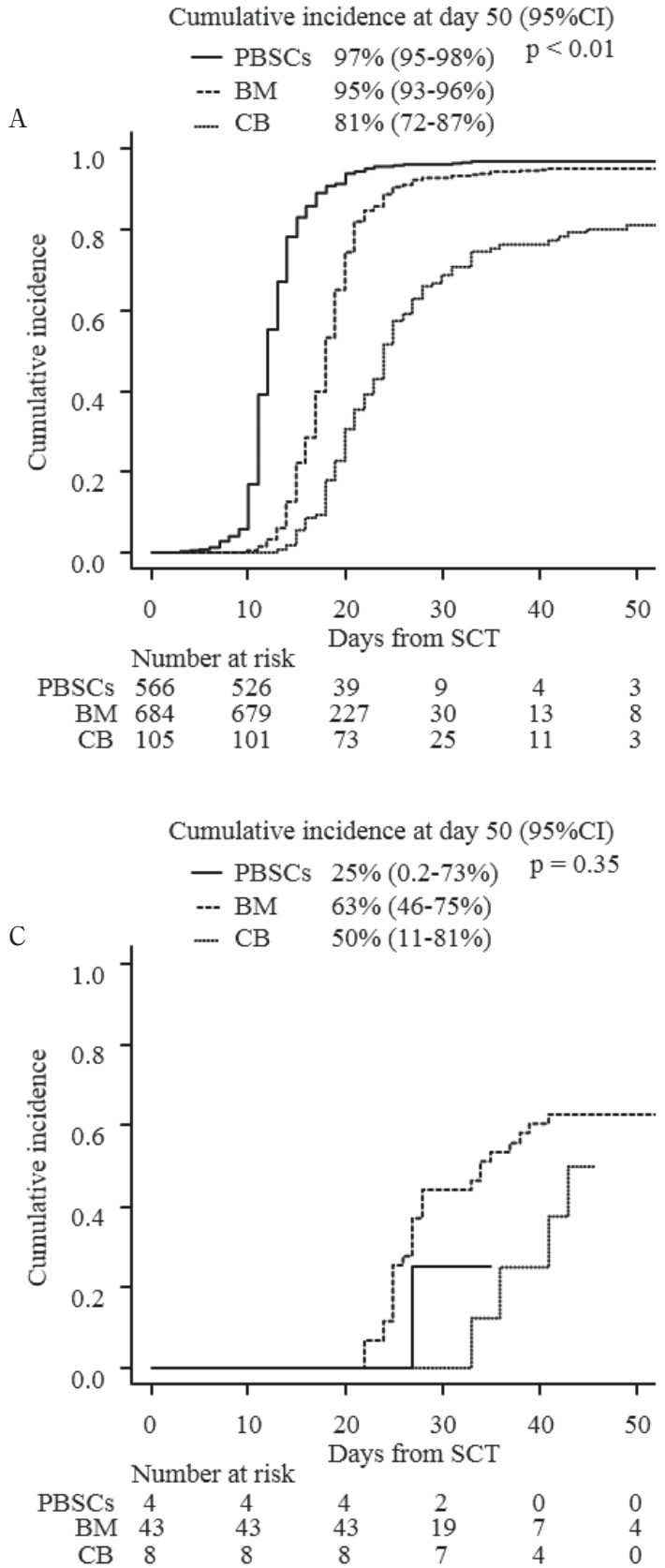
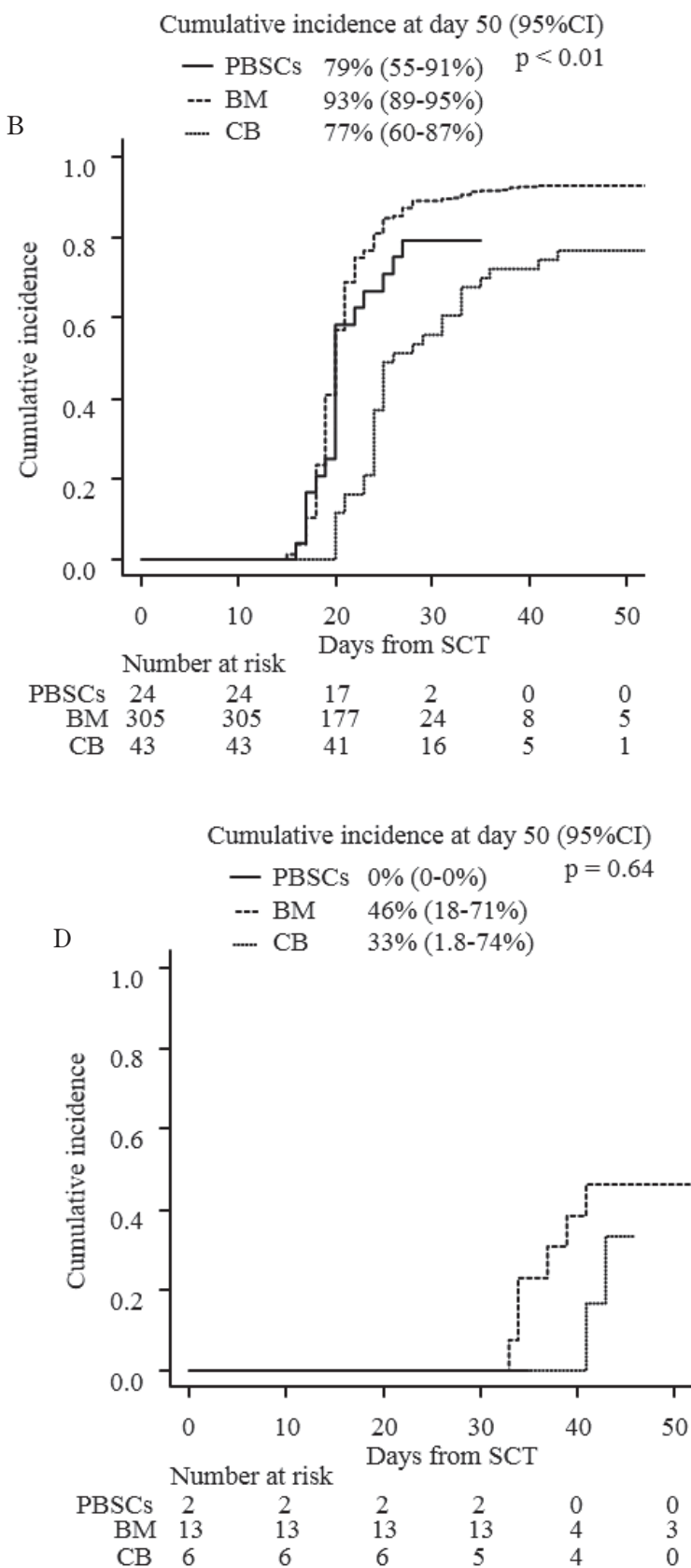

Figure 1. Cumulative incidences of engraftment of all patients and patients with WBCs $\angle 100 \mathrm{cells} / \mu \mathrm{L}$ at a specific day (A) All patients, (B) day 14,(C) day 21, (D) day 28. WBCs, white blood cells; PBSCs, peripheral blood stem cells; BM, bone marrow; CB, cord blood.

ment at day 50: day 21, PBSCs vs. $\mathrm{BM}$ vs. $\mathrm{CB}=25 \%$ vs. $63 \%$ vs. $50 \%, P=0.35$, Figure $1 \mathrm{C}$; day 28 , PBSCs vs. $\mathrm{BM}$ vs. $\mathrm{CB}=0 \%$ vs. $46 \%$ vs. $33 \%, P=0.64$, Figure $1 \mathrm{D})$.

To evaluate the dynamics demonstrating the means by which the probability of engraftment decreased in patients without detectable WBC count, the curves of cumulative incidences of engraftment in patients with WBCs $<100$ cells $/ \mu \mathrm{L}$ from day 10 to day 28 every other day were integrated into one figure as shown in Figure 2. In recipients of BM, the probability of engraftment was $95 \%$ when WBCs were $<100$ cells $/ \mu \mathrm{L}$ at day 10 and was comparable to the probability of all the recipients of BM.
However, the probability started decreasing prominently when WBCs remained at $<100$ cells $/ \mu \mathrm{L}$ beyond day $18-20$; it dropped to $52 \%$ in patients with $\mathrm{WBCs}<100$ cells $/ \mu \mathrm{L}$ at day 22 (Figure 2A). In recipients of PBSCs, the probability of engraftment also started decreasing when their WBCs remained at $<100$ cells $/ \mu$ L beyond day 14 , and it dropped to $40 \%$ in patients with $\mathrm{WBCs}<$ 100 cells/ $\mu \mathrm{L}$ at day 20 (Figure 2B). In recipients of CB, the probability of engraftment started decreasing when their WBCs remained at $<100$ cells $/ \mu \mathrm{L}$ beyond day 20 , and it decreased to $33 \%$ in patients with $\mathrm{WBCs}<100$ cells/ $\mu \mathrm{L}$ at day 24 (Figure 2C). Supplementary table 1 

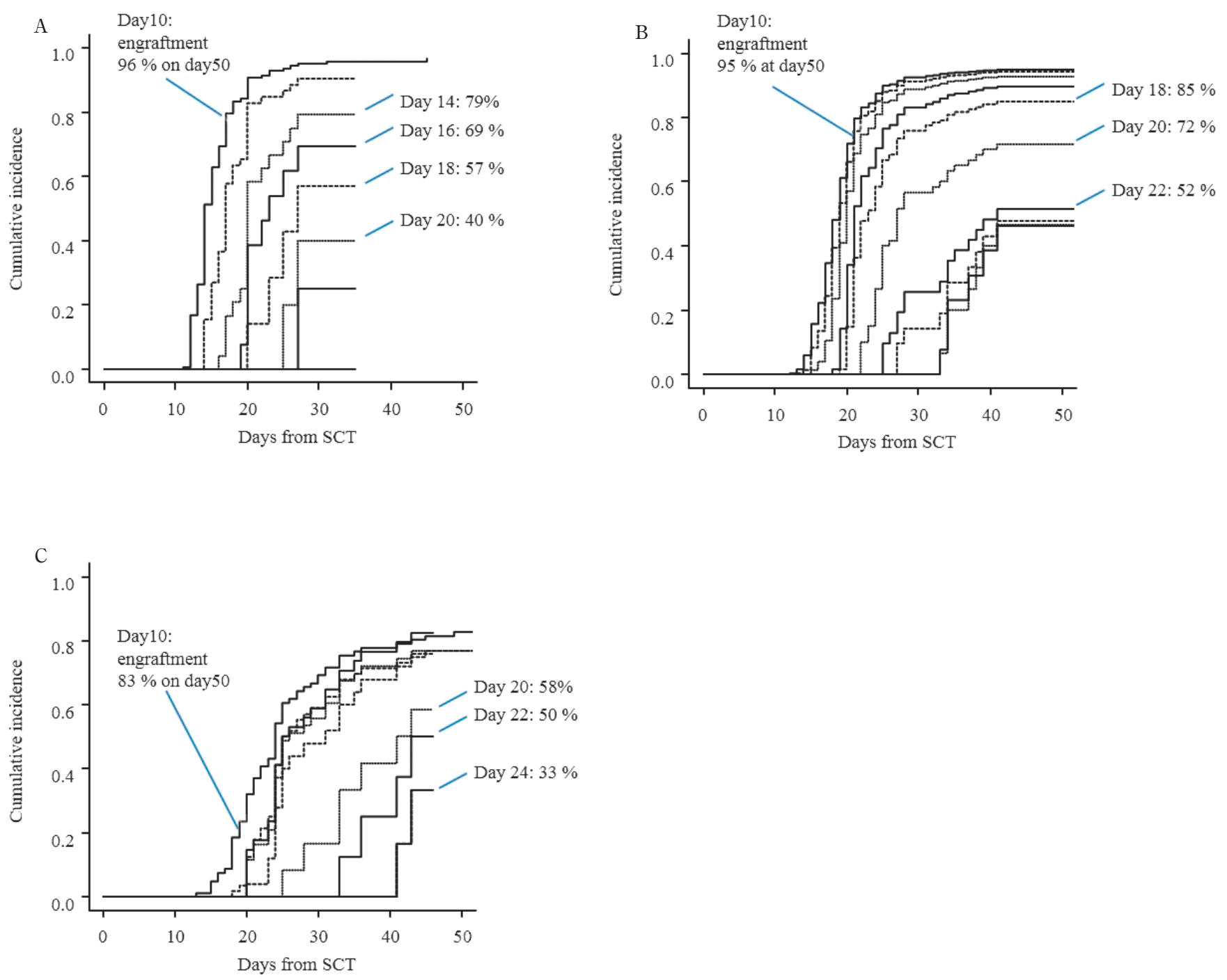

Figure 2. Merged curves of cumulative incidences of neutrophil engraftment of patients with WBCs $<100$ cells $/ \mu \mathrm{L}$ from day 10 to day 28 every other day according to their engraftment sources

(A) PBSCs, (B) BM, (C) CB. WBCs, white blood cells; PBSCs, peripheral blood stem cells; BM, bone marrow; CB, cord blood.

shows more detailed data about the cumulative incidences of engraftment in patients with WBCs $<100$ cells $/ \mu \mathrm{L}$ at each day corresponding to their stem cell sources.

Donor chimerism was used to diagnose primary graft failure and make decisions for the need for retransplantation. Thus, we assessed how the donor chimerism affected the subsequent engraftment in patients with WBCs $<100$ cells $/ \mu \mathrm{L}$ around day 28 . The cumulative incidence of engraftment in patients with donor chimerism $\geq 95 \%$ was significantly higher than the patients with donor chimerism $<95 \%$ ( $100 \%$ vs. $13 \%, P<0.01$, Figure 3).

We observed that the probability of engraftment in recipients of $\mathrm{CB}$ was significantly lower than those of BM or PBSCs. Thus, we performed a subgroup analysis that included recipients of $\mathrm{CB}$, focusing on the use of immunosuppressive drugs, since patients who received cyclosporin $\mathrm{A}(\mathrm{CyA})$ plus mycophenolate mofetil (MMF) as immunosuppressants were reported to achieve engraftment significantly earlier than those who received CyA plus methotrexate $(\text { MTX })^{18,19}$. Supplementary Figure 2 shows that patients who received calcineurin inhibitors plus MMF achieved significantly early engraftment compared with those who received calcineurin inhibitors plus MTX $(P<0.01)$.

Supplementary table 2 shows the results of univariate analyses for engraftment in all patients and patients with WBCs $<100$ cells $/ \mu \mathrm{L}$ at day 14,21 , and 28 . Table 3 presents the results of multivariate analyses of engraftment in all patients and patients with WBCs $<100$ cells/ $\mu \mathrm{L}$ at day 14 . The factors that were associated with the incidence of subsequent engraftment differed between all patients and patients with $\mathrm{WBCs}<100$ cells $/ \mu \mathrm{L}$ at day 14. Infection was the only significant risk factor in both the patients with $\mathrm{WBCs}<100$ cells $/ \mu \mathrm{L}$ at day 14 as well as all patients. We omitted multivariate analyses in 
patients with $\mathrm{WBCs}<100$ cells $/ \mu \mathrm{L}$ at day 21 and 28 because the number of patients was too small for multivariate analyses.

\section{Discussion}

In our study, we retrospectively assessed the cumulative incidences of engraftment, mortality without engraftment, and re-transplantation in recipients of allo-SCT at each day following allo-SCT. Our data, for the first time, showed that dynamic alteration in the expected probability of subsequent engraftment differed clearly among

Cumulative incidence at day $50(95 \% \mathrm{CI})$

Around day 28 donor chimerism

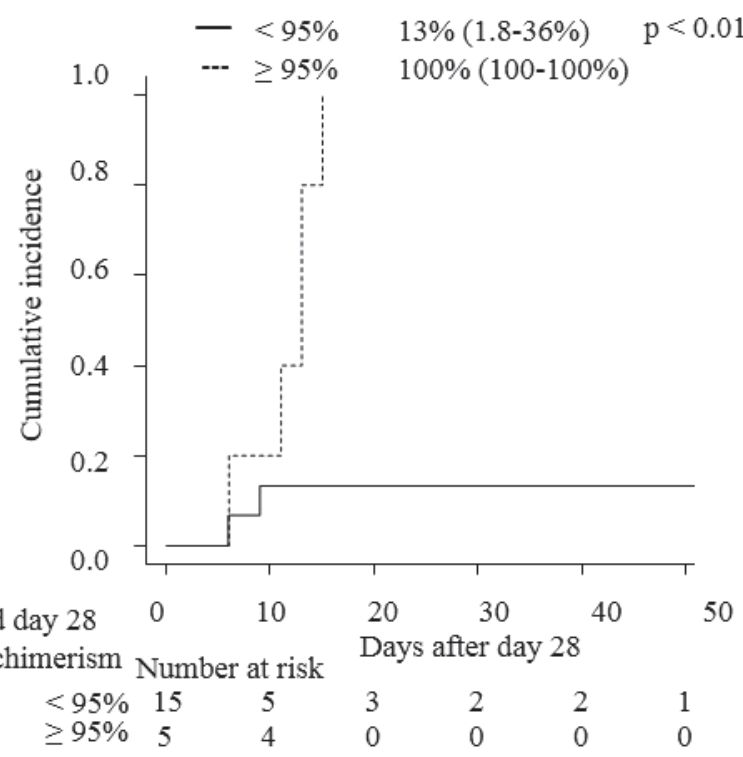

Figure 3. Cumulative incidences of engraftment according to donor chimerism in the patients with WBCs $<100$ cells $/ \mu \mathrm{L}$ at day 28

WBCs, white blood cells. stem cell sources. These data provided us information about the expected probability of subsequent engraftment and the need of retransplantation in patients whose WBCs remained undetectable, which would give us a clue regarding a reasonable timing to assess the engraftment, including chimerism analysis and $\mathrm{BM}$ aspiration.

In our analyses, chimerism around day 28 strongly predicted subsequent engraftment. However, our results suggested that patients already face the risk of primary graft failure before day 28, especially in recipients of PBSCs. Therefore, it might be helpful to decide the appropriate timing to assess donor chimerism earlier than day 28, taking both their source of stem cells and WBC counts into account. If the donor chimerism is low, it is desirable to plan a salvage $\mathrm{SCT}^{5,6,20}$. If the complete donor chimerism is confirmed, waiting for the engraftment of WBCs or intervention against poor graft function, such as stem cell boost, immunosuppression therapy, or salvage SCT are considered $^{21-25}$.

In addition, in patients who received $\mathrm{CB}$, use of MMF apparently changed the kinetics of engraftment. The significantly higher risk of primary graft failure after $\mathrm{CB}$ transplant than after allo-SCT using BM or PBSCs is consistent with previous reports ${ }^{18,19}$. Furthermore, the duration of neutropenic period was longer in recipients of $\mathrm{CB}$ in spite of the engraftment being successfully achieved. Thus, it is particularly important to identify patients at high risk of primary graft failure in recipients of $\mathrm{CB}$. The kinetics of engraftment and risk of graft failure after single CB transplantation were previously reported $^{26}$. In their report, the likelihood of engraftment peaked at day 21 and decreased subsequently. In our analyses, the probability of subsequent engraftment decreased from day 20 as long as WBC remained $<100$ cells $/ \mu \mathrm{L}$, which was consistent with their report ${ }^{26}$. Thus, these time points would be practically appropriate to

Table 3. Multivariate analyses of cumulative incidence of engraftment at day 50 in all patients and patients with WBCs $<100$ cells $/ \mu \mathrm{L}$ at day 14

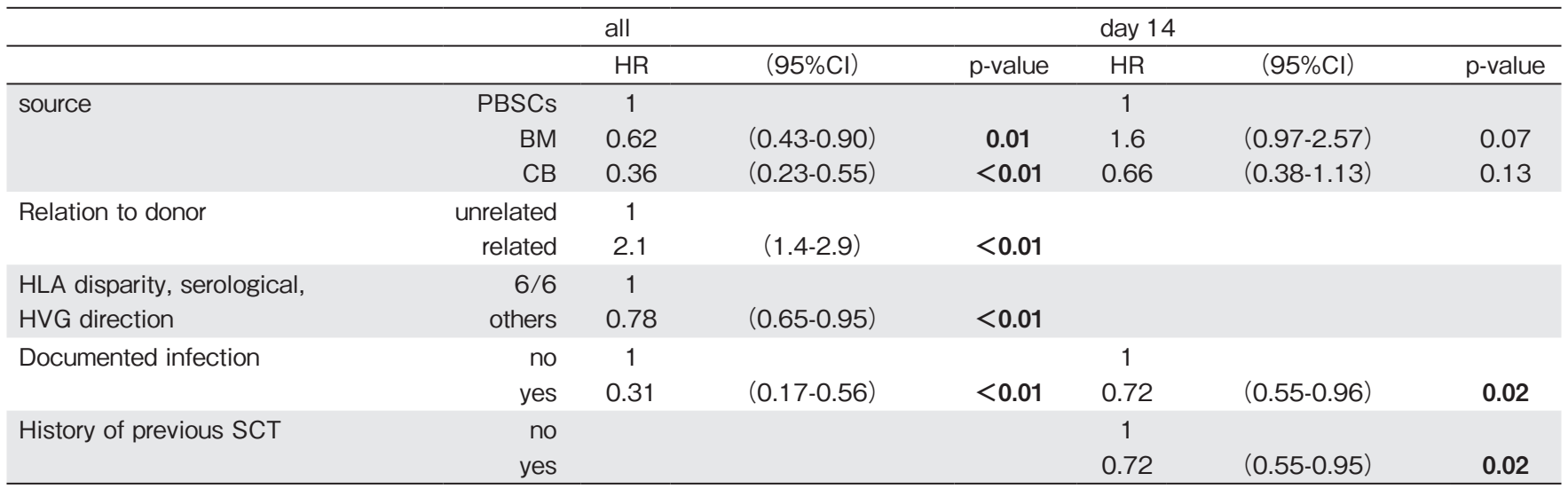

WBC, white blood cell; PBSCs, peripheral blood stem cells; BM, bone marrow; CB, cord blood; HLA, human leukocyte antigen; HVG, hostversus-graft; SCT, stem cell transplantatuon. 
evaluate chimerism and $\mathrm{BM}$ aspirate to precisely assess the risk of primary graft failure.

The univariate and multivariate analyses suggested that several clinical factors were predictive of subsequent engraftment in all patients and patients with $\mathrm{WBCs}<100$ cells $/ \mu \mathrm{L}$ at specific time points. It is important to differentiate these prognostic factors across different time points and in different conditions. For example, on the one hand, BM was a significant risk factor against engraftment in the analysis for all patients compared with PBSCs. On the other hand, BM was a favorable factor for engraftment in the analysis for patients with $\mathrm{WBCs}<100$ cells/ $\mu \mathrm{L}$ at day 14 compared with PBSCs. This clearly means that engraftments and WBC recoveries were generally earlier with PBSCs than with BM and CB. Thus, patients whose WBCs remained $<100$ cells $/ \mu \mathrm{L}$ at day 14 were especially at risk of graft failure.

The limitations of this study should be clarified. First, it is not clear whether patients who died without engraftment could have been successfully rescued if they had received re-transplantation promptly. However, given the dismal outcome in patients with primary graft failure, there might be many patients who could avoid death and attain engraftment if other complications, such as infection and organ failure were successfully controlled. Secondly, the criterion of the $\mathrm{WBCs}<100$ cells $/ \mu \mathrm{L}$ was used to define patients with uncountable WBCs in this study. However, this threshold might be higher than that in other institutes. Thus, our findings should be reassessed in other institutes. Thirdly, this study only evaluated whether patients achieved neutrophil engraftment or not, which means that we did not distinguish primary graft failure with no donor chimerism from poor graft function with mixed/complete donor chimerism. Although they should have been theoretically treated using different methods, due to a limited number of patients, it was difficult to compare the effectiveness of methods such as salvage SCT or stem cell boost to rescue such patients. Our study provided information for appropriate timing to evaluate the probability of subsequent engraftment. Fourthly, the data of donor chimerism were available only around day 28 . We need more data to assess whether data of donor chimerism around day 14 or 21 were more advantageous or not. To determine the best treatment option for patients at high risk of primary graft failure, larger studies are needed to compare the effectiveness among the treatment options.

In conclusion, although the probabilities of engraftment decreased if WBCs remained undetectable long time, the dynamic alterations varied significantly according to stem cell sources. In addition to pre-transplant risk factors, post-transplant WBC kinetics would help us to estimate the risk of primary graft failure, which in turn might be useful to diagnose primary graft failure at an appropriate timing, to promptly schedule patients with primary graft failure for a second transplantation.

\section{Acknowledgements}

This work was supported by grants from the National Cancer Research and Development Fund (26-A-26) and the Advanced Clinical Research Organization.

\section{Authors' Contribution}

A. K. and S. F. designed this study and analyzed the data; all authors wrote the manuscript.

\section{Financial Support}

Akihisa Kawajiri received financial support from grants from National Cancer Research and Development Fund, grants from Advanced Clinical Research Organization.

\section{Conflict of Interest}

The authors declare no conflict of interest. Disclosure forms provided by the authors are available here.

\section{References}

1. Mattsson J, Ringden O, Storb R. Graft failure after allogeneic hematopoietic cell transplantation. Biol Blood Marrow Transplant. 2008; 14 (1 Suppl 1): 165-70.

2. Gerson SL, Talbot GH, Hurwitz S, Strom BL, Lusk EJ, Cassileth PA. Prolonged granulocytopenia: The major risk factor for invasive pulmonary aspergillosis in patients with acute leukemia. Annals of Internal Medicine. 1984; 100: 345-51.

3. Schriber J, Agovi MA, Ho V, Ballen KK, Bacigalupo A, Lazarus HM, et al. Second unrelated donor hematopoietic cell transplantation for primary graft failure. Biol Blood Marrow Transplant. 2010; 16: 1099-106.

4. Rondon G, Saliba RM, Khouri I, Giralt S, Chan K, Jabbour E, et al. Long-term follow-up of patients who experienced graft failure postallogeneic progenitor cell transplantation. Results of a single institution analysis. Biol Blood Marrow Transplant. 2008; 14: 859-66.

5. Waki F, Masuoka K, Fukuda T, Kanda Y, Nakamae M, Yakushijin $\mathrm{K}$, et al. Feasibility of reduced-intensity cord blood transplantation as salvage therapy for graft failure: results of a nationwide survey of adult patients. Biol Blood Marrow Transplant. 2011; 17: 841-51.

6. Fuji S, Nakamura F, Hatanaka K, Taniguchi S, Sato M, Mori S, et al. Peripheral blood as a preferable source of stem cells for salvage transplantation in patients with graft failure after cord blood transplantation: a retrospective analysis of the registry 
data of the Japanese Society for Hematopoietic Cell Transplantation. Biol Blood Marrow Transplant. 2012; 18: 1407-14.

7. Cluzeau T, Lambert J, Raus N, Dessaux K, Absi L, Delbos F, et al. Risk factors and outcome of graft failure after HLA matched and mismatched unrelated donor hematopoietic stem cell transplantation: a study on behalf of SFGM-TC and SFHI. Bone Marrow Transplant. 2016; 51: 687-91.

8. Le Blanc K, Remberger M, Uzunel M, Mattsson J, Barkholt L, Ringdén O. A Comparison of Nonmyeloablative and ReducedIntensity Conditioning for Allogeneic Stem-Cell Transplantation. Transplantation. 2004; 78: 1014-20.

9. Ciurea SO, de Lima M, Cano P, Korbling M, Giralt S, Shpall EJ, et al. High Risk of Graft Failure in Patients With Anti-HLA Antibodies Undergoing Haploidentical Stem-Cell Transplantation. Transplantation. 2009; 88: 1019-24.

10. Ciurea SO, Thall PF, Wang X, Wang SA, Hu Y, Cano P, et al. Donor-specific anti-HLA Abs and graft failure in matched unrelated donor hematopoietic stem cell transplantation. Blood. 2011; 118: 5957-64.

11. Cutler C, Kim HT, Sun L, Sese D, Glotzbecker B, Armand P, et al. Donor-specific anti-HLA antibodies predict outcome in double umbilical cord blood transplantation. Blood. 2011; 118: 6691-7.

12. Ruggeri A, Rocha V, Masson E, Labopin M, Cunha R, Absi L, et al. Impact of donor-specific anti-HLA antibodies on graft failure and survival after reduced intensity conditioning-unrelated cord blood transplantation: a Eurocord, Societe Francophone d'Histocompatibilite et d'Immunogenetique (SFHI) and Societe Francaise de Greffe de Moelle et de Therapie Cellulaire (SFGM-TC) analysis. Haematologica. 2013; 98: 115460.

13. Kawashima N, Terakura S, Nishiwaki S, Koyama D, Ozawa Y, Ito $\mathrm{M}$, et al. Increase of bone marrow macrophages and CD8 (+) T lymphocytes predict graft failure after allogeneic bone marrow or cord blood transplantation. Bone Marrow Transplant. 2017; 52: 1164-70.

14. Moscardó F, Sanz J, Senent L, Cantero S, de la Rubia J, Montesinos P, et al. Impact of hematopoietic chimerism at day +14 on engraftment after unrelated donor umbilical cord blood transplantation for hematologic malignancies. Haematologica. 2009; 94: 827-32.

15. Oken MM, Creech RH, Tormey DC, Horton J, Davis TE, McFadden ET, et al. Toxicity and response criteria of the Eastern Cooperative Oncology Group. American journal of clinical oncology. 1982; 5: 649-55.

16. Armand P, Kim HT, Logan BR, Wang Z, Alyea EP, Kalaycio ME, et al. Validation and refinement of the Disease Risk Index for allogeneic stem cell transplantation. Blood. 2014; 123: 3664-71.
17. Kanda Y. Investigation of the freely available easy-to-use software 'EZR' for medical statistics. Bone marrow transplantation. 2013; 48: 452-8.

18. Bolwell B, Sobecks R, Pohlman B, Andresen S, Rybicki L, Kuczkowski E, et al. A prospective randomized trial comparing cyclosporine and short course methotrexate with cyclosporine and mycophenolate mofetil for GVHD prophylaxis in myeloablative allogeneic bone marrow transplantation. Bone Marrow Transplant. 2004; 34: 621-5.

19. Ram R, Yeshurun M, Vidal L, Shpilberg O, Gafter-Gvili A. Mycophenolate mofetil vs. methotrexate for the prevention of graft-versus-host-disease--systematic review and meta-analysis. Leuk Res. 2014; 38: 352-60.

20. Fuji S. Haploidentical Related Peripheral Blood Stem Cell Transplantation as a Salvage Transplantation in Patients with Graft Failure. Internal Medicine. 2015; 54: 2709-10.

21. Larocca A, Piaggio G, Podesta M, Pitto A, Bruno B, Di Grazia $\mathrm{C}$, et al. Boost of CD34 + -selected peripheral blood cells without further conditioning in patients with poor graft function following allogeneic stem cell transplantation. Haematologica. 2006; 91: 935-40.

22. Klyuchnikov E, El-Cheikh J, Sputtek A, Lioznov M, Calmels B, Furst S, et al. CD34 + -Selected Stem Cell Boost without Further Conditioning for Poor Graft Function after Allogeneic Stem Cell Transplantation in Patients with Hematological Malignancies. Biology of Blood and Marrow Transplantation. 2014; 20: 382-6.

23. Haen SP, Schumm M, Faul C, Kanz L, Bethge WA, Vogel W. Poor graft function can be durably and safely improved by CD34 + -selected stem cell boosts after allogeneic unrelated matched or mismatched hematopoietic cell transplantation. Journal of Cancer Research and Clinical Oncology. 2015; 141: 2241-51.

24. Stasia A, Ghiso A, Galaverna F, Raiola AM, Gualandi F, Luchetti S, et al. CD34 Selected Cells for the Treatment of Poor Graft Function after Allogeneic Stem Cell Transplantation. Biology of Blood and Marrow Transplantation. 2014; 20: 1440-3.

25. Takagi S, Masuoka K, Uchida N, Ishiwata K, Araoka H, Tsuji $\mathrm{M}$, et al. High incidence of haemophagocytic syndrome following umbilical cord blood transplantation for adults. British Journal of Haematology. 2009; 147: 543-53.

26. Ruggeri A, Labopin M, Sormani MP, Sanz G, Sanz J, Volt F, et al. Engraftment kinetics and graft failure after single umbilical cord blood transplantation using a myeloablative conditioning regimen. Haematologica. 2014; 99: 1509-15.

doi: https: //doi.org/10.31547/bct-2018-011 Copyright (C) 2019 APBMT. All Rights Reserved. 